\title{
Effect of Drought on Storage Root Development and Gene Expression Profile of Sweetpotato under Greenhouse and Field Conditions
}

\author{
Julio Solis \\ School of Plant, Environmental, and Soil Sciences, Louisiana State University Agricultural Center, \\ Baton Rouge, LA 70803 \\ Arthur Villordon \\ Sweet Potato Research Station, Louisiana State University Agricultural Center, 130 Sweet Potato \\ Road, Chase, LA 71324 \\ Niranjan Baisakh and Don LaBonte ${ }^{1}$ \\ School of Plant, Environmental, and Soil Sciences, Louisiana State University Agricultural Center, \\ Baton Rouge, LA 70803 \\ Nurit Firon \\ Institute of Plant Sciences, The Volcani Center, ARO, P.O. Box 6, Bet Dagan, 50250, Israel
}

\begin{abstract}
AdDITIONAL INDEX woRDs. differential gene expression, drought stress, Ipomoea batatas, regulatory genes, storage root formation, yield

Abstract. Greenhouse and field culture systems were used to study the effect of drought conditions on the storage root (SR) formation in 'Beauregard' sweetpotato (Ipomoea batatas). In the greenhouse culture system, drought was simulated by withholding water for 5 and 10 days after transplanting (DAT) cuttings in dry sand. Control plants received water at planting and every 3 days thereafter. In the field studies, natural drought conditions and selective irrigation were used to impose water deprivation during the critical SR formation period. Greenhouse drought for 5 and 10 DAT reduced the number of SRs by $42 \%$ and $66 \%$, respectively, compared with the controls. Field drought resulted in a 49\% reduction in U.S. \#1 SR yield compared with the irrigated condition. Quantitative real-time polymerase chain reaction (PCR) analysis showed differential expression of a set of sweetpotato transcription factors and protein kinases among greenhouse-grown plants subjected to well-watered conditions and water deficit during 5 DAT. A significant enhancement of expression was observed for known drought stress-associated genes such as an abscisic acid-responsive elements-binding factor, dehydration-responsive element-binding factor, and homeodomain-zip proteins. Members of calcium-binding proteins showed differential expression under drought stress. For the first time it is reported that knotted1-like homeobox and BEL1-like genes showed altered expression in response to drought stress under a greenhouse condition. In summary, the results suggest that water deprivation during the SR formation period influences root development and expression patterns of stress-responsive genes and those previously found associated with SR formation in sweetpotato.
\end{abstract}

Drought stress represents a global constraint for sweetpotato production because most of the sweetpotato production occurs in semiarid regions (Saraswati, 2007). Considering the complexity of the physiological and genetic mechanisms associated with stress tolerance, a genomics-based understanding of the stress response of sweetpotato will help us develop strategies to sustain its productivity in stressful environments (Boyer, 1982). Candidate drought-responsive genes, identified through genomics research, will have great use in widening the natural allelic variation and its possible use for crop improvement (Rus et al., 2006). However, sweetpotato has lagged with respect to studies leading to the identification of its drought-responsive genes. One study reported 12 genes in response to drought stress in white fibrous roots (Kim et al., 2009), and most of these genes

Received for publication 13 Jan. 2014. Accepted for publication 2 Mar. 2014. Approved for publication by the Director of the Louisiana Agricultural Experiment Station as manuscript number 2013-306-10779.

Support for this research was provided by a grant from The USA-Israel Binational Agricultural Research and Development grant number US-4015-07.

${ }^{1}$ Corresponding author. E-mail: dlabonte@agcenter.lsu.edu. are similar to ones that are known to be associated with dehydration response in many other species. A dehydration responsive element-binding protein gene, a member of the AP2 (Apetala2)/EREBP (ethylene-responsive element binding protein) family, has been characterized in drought-stressed roots and stems of sweetpotato (Kim et al., 2008). Evidence of the genetic basis of sweetpotato tolerance to drought comes from studies carried out in vitro along with field and greenhouse experiments (Ekanayake and Dodds, 1993; Ricardo, 2011). Genes associated with antioxidant activity were up-regulated in leaves under drought and salt stress (Kim et al., 2013). Similarly, transcripts of late embryogenesis abundant proteins, known to be associated with abiotic stress responses, were increased with lignification in sweetpotato tissue cultures (Park et al., 2011). These studies collectively demonstrate that abiotic cues result in transcriptional changes in sweetpotato. However, gene expression under stress has not been studied in early stages of storage root development, before thickening of roots.

Sweetpotato SRs develop from adventitious roots emerging from root primordia located on stem nodes. Unknown intrinsic 
and extrinsic factors trigger thickening of these adventitious roots, the process known as SR initiation. SR initiation has been defined as the formation of a cambium ring and appearance of anomalous cambia around discrete xylem and protoxylem elements within $20 \mathrm{~d}$ of the emergence of an adventitious root (Togari, 1950). Greenhouse and field culture systems in 'Beauregard' validated that SR initiation consistently occurred during the first $20 \mathrm{~d}$ after transplanting (Villordon et al., 2009a, 2009 b). Preformed primordia that produce adventitious roots with pentarch, hexarch, or septarch steles have the potential to develop into SRs (Villordon et al., 2009b). However, damage to the root primordia, unfavorable edaphoclimatic conditions, and age of nodes influence the total SR in a cultivar.

Although previous molecular studies during the past decade have reported several candidate genes to be up-regulated or expressed preferentially in SRs, no single gene has been shown to be solely responsible for conversion of the adventitious roots into storage organs (Kim et al., 2002, 2005; Ku et al., 2008; Noh et al., 2010; Tanaka et al., 2008; You et al., 2003). Most of these genes have either regulatory roles as transcription factors or are involved in carbohydrate and protein metabolism during the development and thickening of the SRs. Firon et al. (2013) have recently demonstrated down-regulation in the expression of key genes of the phenylpropanoid biosynthesis pathway on the change in root fate from fibrous root to a storage organ. In addition, precise control at the level of gene expression of regulators of meristematic tissue identity and maintenance, upregulation of cell-division regulators, and down-regulation of specific GRAS [GAI (gibberellin acid-insensitive), RGA (repressor of GA1), SCR (scarecrow)] family members in the SR-initiation process were indicated.

The present study was undertaken to examine the effect of drought stress on the SR formation under greenhouse and field conditions and to characterize the expression of a selected set of genes in root tissues of drought-stressed vs. non-stressed plants. The genes included in this study were selected based on their 1) role in gene regulation and calcium signaling during developmental and physiological processes; 2) enrichment in root libraries (GenBank; Firon et al., 2013; Schafleitner et al., 2010); 3 ) role in drought stress responses and hormone signaling; and 4) functional homology to genes known to be involved in storage organ development in other crops such as potato [Solanum tuberosum (Reddy et al., 2002)] and cassava [Manihot esculenta (de Souza et al., 2004)].

\section{Materials and Methods}

Plant material. Sweetpotato plant cuttings $(\approx 20 \mathrm{~cm}$ long $)$ were obtained from generation 0 (derived from in vitro cultures) virus-tested, greenhouse-grown 'Beauregard' for greenhouse studies and virus-tested generation 1 seed roots in plant beds for field studies.

DROUGHT STUDIES UNDER GREENHOUSE CONDITIONS. Unrooted cuttings ( $\mathrm{n}=9$ for each of the three treatments) were prepared and transplanted the same day in dry sand in cylindrical tubes $(50 \times 9.82 \mathrm{~cm})$ under greenhouse conditions. Plants were grown inside the greenhouse under a day/night temperature regime of $27 / 21{ }^{\circ} \mathrm{C}$ for Trial 1 (30 Jan. 2011 to 10 Mar. 2011) and 28/ $25^{\circ} \mathrm{C}$ for Trial 2 (9 May 2011 to 21 June 2011), respectively, at 50 to $70 \mu \mathrm{mol} \cdot \mathrm{m}^{-2} \cdot \mathrm{s}^{-1}$; no artificial lighting was provided. Our earlier pilot experiments indicated that the cuttings could survive at least 10 DAT into dry sand under controlled conditions.
Drought stress was imposed by withholding water for 5 and 10 DAT and control plants received water the same day of transplanting (0 DAT). Subsequently, stressed plants received water every $3 \mathrm{~d}$, whereas the control plants received water every $3 \mathrm{~d}$ throughout the experiment. Each treatment included nine plants. Cuttings were watered $(400 \mathrm{~mL})$ every $3 \mathrm{~d}$ after the initial 5- and 10-d treatment period. Water-soluble $20 \mathrm{~N}-8.7 \mathrm{P}-16.6 \mathrm{~K}$ solution (Peters Professional Soluble Plant Food; Scotts-Sierra, Marysville, $\mathrm{OH})$ was applied $(0.374 \mathrm{~g} / 200 \mathrm{~mL})$ at 12 and 22 DAT. Four weeks after transplanting, the plants were evaluated for the number of SRs (width greater than $1.5 \mathrm{~mm}$ ) and the width and weight of the SRs. Thin pigmented roots (width less than $1.5 \mathrm{~mm}$ ) were included in the total count of SRs (SRCount1) because we considered them as putative-forming/developing SRs. A second count of SRs (SRCount2) excluded these pigmented SRs. Maximum diameters of SRs were measured with a caliper. The experiments were repeated twice.

A second study was carried out in the greenhouse to evaluate expression of a set of selected genes (Table 1) in total roots from initially drought-stressed (no water for 5 DAT) and wellwatered (control) plants. The initial water stress at planting may resemble unfavorable drought conditions met by farmers, where cuttings are left in soil without watering until rainfall arrives. Fertilizer was applied at 12 DAT. Roots from these plants were sampled at 14 DAT in triplicate by pooling roots from three plants and then the roots were frozen in liquid nitrogen. Root tissues were stored at $-80^{\circ} \mathrm{C}$; the experiment was repeated twice.

Drought STUdies UNDER FIELd CONDitions. Field experiments were conducted in the Summer 2010 and 2011 in welldrained research fields at Chase, LA (lat. $32^{\circ} 6^{\prime} \mathrm{N}$, long. $91^{\circ} 42^{\prime} \mathrm{W}$ ). The soil taxonomic class was fine-silty, mixed, active, thermic Typic Glossaqualfs. There were three planting dates in 2010 (12 May, 27 May, and 3 June) and two planting dates in 2011 (19 May and 1 June). In each year, natural rainfall deficits during May and June created conditions where soil moisture in the root zone was near the wilting point for the soil type used in the studies. The rainfall pattern during the time of experiments in 2010 and 2011 is shown in Figure 1. Rickard and Fitzgerald (1969) defined agricultural drought as existing when the soil moisture in the root zone is at or below wilting point. During June to Aug. 2011, portions of northeastern Louisiana, including the location of the field experiments, had record low values for the Palmer hydrological drought index in the 117-year record (Blunden and Arndt, 2012). These growing conditions were used to compare SR yield from plots with drought-stressed (non-irrigated) vs. plots that were irrigated to maintain soil moisture at $50 \%$ of field capacity (FC) during the SR initiation phase, which can occur as early as 13 DAT in 'Beauregard' grown in field plots (Villordon et al., 2009b). Field preparation activities, including fertilizer rates, herbicide, and insecticide applications, were similar in each year as previously described (Villordon et al., 2009b, 2011). Supplemental overhead irrigation was supplied with a traveling irrigation sprinkler if a rainfall event did not occur in irrigated plots.

In each planting date, two plots were designated as irrigated vs. non-irrigated plots. Plot size was 12 rows $\times 30 \mathrm{~m}$ on $1-\mathrm{m}$ centers. The plots were separated by a buffer zone equivalent to 12 rows. Supplemental irrigation was based on soil moisture sensor data and irrigation was applied when soil moisture at the $15-\mathrm{cm}$ depth approached $25 \%$ of FC. A $16 \%$ volumetric water content (VWC) represented $50 \%$ of FC in this study. This soil moisture range has previously been calibrated (Constantin et al., 


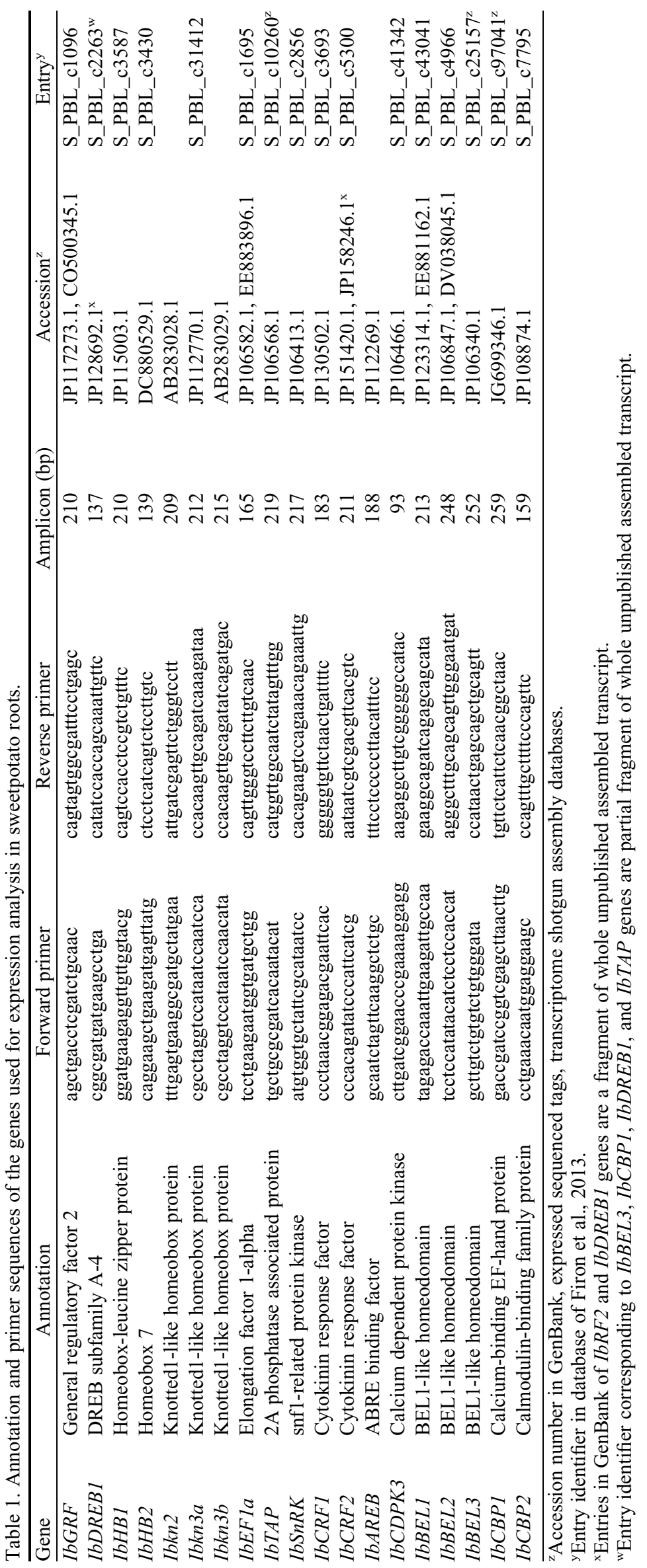



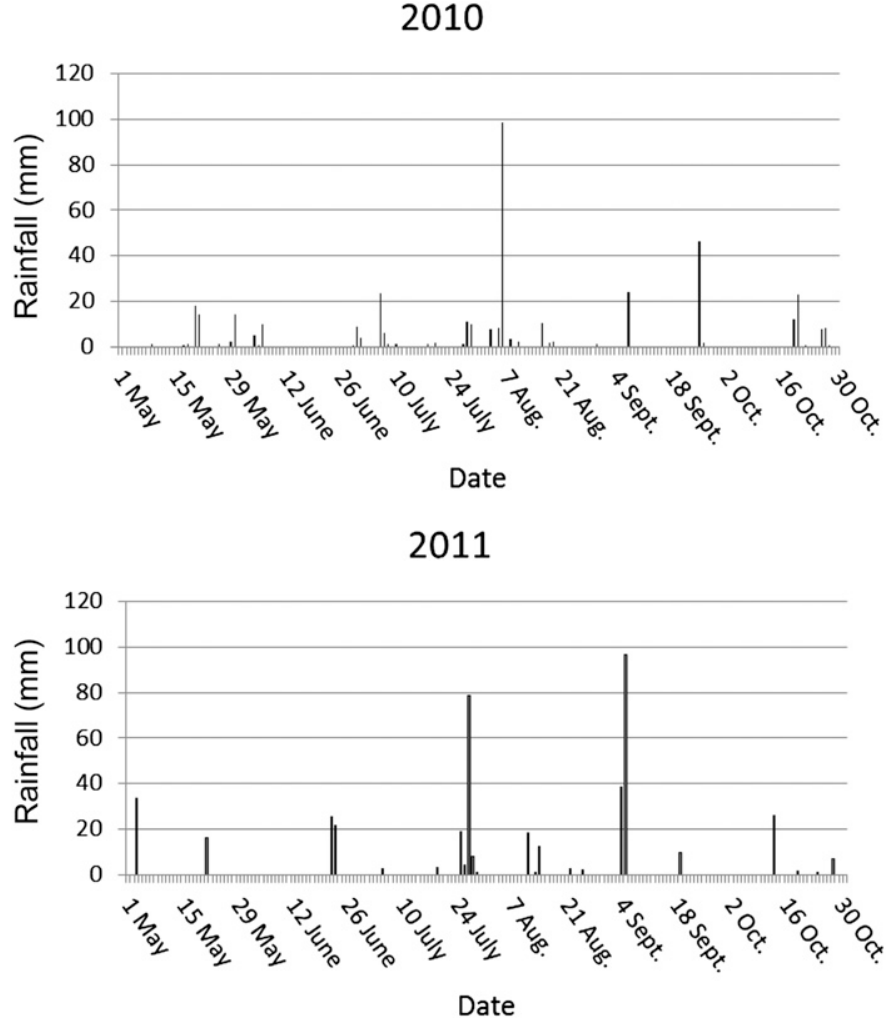

Fig. 1. Rainfall data of Chase, LA, during the experiments of 2010 and 2011 to study the effect of drought stress on storage root yield of sweetpotato (National Oceanic and Atmospheric Administration, 2014).

1974) and validated (Villordon et al., 2010) as optimum for 'Beauregard' grown in north Louisiana. Soil moisture monitoring at two depths (5 and $15 \mathrm{~cm}$ ) was performed by vertically installed soil moisture sensors (Model 5TE; Decagon Devices, Pullman, WA) linked to automated data loggers (EM50; Decagon Devices). All supplemental irrigation was delivered through a traveling irrigation sprinkler or furrow irrigation (after 35 DAT). For non-irrigated plots, soil moisture was consistently below or at levels defined as the wilting point during the SR formation period. In 2010, soil moisture at the $15-\mathrm{cm}$ depth stayed below $10 \%$ VWC during the first $30 \mathrm{~d}$ of growth in non-irrigated plots. This range has been previously defined as the witling point for this soil type (Ley et al., 1994). In 2011, soil moisture at the 15-cm depth ranged from $9 \%$ to $11 \%$ VWC during the first $30 \mathrm{~d}$ of growth in non-irrigated plots. All plots subsequently received natural rainfall events, which precluded supplemental irrigation. At harvest, a two-row section ( $6 \mathrm{~m}$ in length) located in the center of each plot was designated as the record rows and used for SR yield measurements. Harvest was at 110 DAT (2010) to 130 DAT (2011) and SRs were graded according to U.S. Department of Agriculture standards (USDA, 2005): U.S. \#1 (5.1 to $8.9 \mathrm{~cm}$ diameter and 7.6 to $22.9 \mathrm{~cm}$ length), Canner $(2.5$ to $5.1 \mathrm{~cm}$ diameter and 5.1 to $17.8 \mathrm{~cm}$ length), and Jumbo (larger than both groups). Total marketable yield was defined as the sum of U.S. \#1, Canner, and Jumbo. The number of SRs classified as U.S. \#1 grade, the premium yield grade, was also counted.

GENE EXPRESSION PROFILING BY QUANTITATIVE REVERSE TRANSCRIPTION PCR (QRT-PCR). RNA was extracted from 2-week-old root tissues using the RNeasy plant minikit (Qiagen, Valencia, CA) following the vendor's protocol. An on-column
DNase I treatment was done to eliminate any contaminating DNA. RNA quality and quantity were determined using a spectrophotometer (NanoDrop ND-1000; Thermo Scientific, Wilmington, DE). cDNA synthesis and quantitative reverse transcription (qRT)-PCR were performed as described earlier (Effendy et al., 2013). Briefly, $2 \mu \mathrm{g}$ of total RNA was reverse transcribed using an iScript cDNA synthesis kit (Bio-Rad, Hercules, CA). The first strand cDNA was diluted three times with water, and $2 \mu \mathrm{L}$ was used for the PCR using the iQSYBR green supermix (Bio-Rad). A melting curve analysis was performed to ensure correct gene amplification product. The sweetpotato elongation factor 1-alpha [IbEFla (Effendy et al., 2013)] (Table 1) was used as the reference gene for normalization of gene expression. Each qRT-PCR reaction was run in triplicate and each gene was tested twice using cDNA made from two independent RNA sample sets from total roots (drought and control). Fold change expression of the genes under drought and control conditions was calculated using the $2^{\text {-ddet }}$ method (Effendy et al., 2013). Primers specific to the 19 genes, including 2 KNOX genes [Ibkn2, Ibkn3 (Tanaka et al., 2008)], used for expression analysis under drought vs. control samples are described in Table 1. Transcription factors such as BELL (IbBEL1, IbBEL2,IbBEL3) and Knox (IbKn2, IbKn3a, IbKn3b) genes were selected because of their role in tuber development in potato (Chen et al., 2003) and sweetpotato and abundance of Knox genes in sweetpotato (Firon et al., 2013; Tanaka et al., 2008). Homeobox domain-containing proteins (IbHB1, IbHB2) and general regulatory factor $(I b G R F)$ were included in the study because of their preponderance in initiating SRs (Firon et al., 2013; Solis, 2012). Cytokinin response genes (IbCRF 1, IbCRF2) were selected because of the role of cytokinin in inducing SR formation (Eguchi and Yoshida, 2008). Abscisic acid responsive element binding protein $(I b A R E B)$ and dehydration responsive element binding protein $(I b D R E B 1)$ genes were selected considering their role in plant responses to abiotic stresses (Choi et al., 2000, 2005). Genes associated with calcium signaling $(I b C B P 1, I b C B P 2, I b C D P K 3)$ and signal transduction (IbTAP) were chosen because of their abundance in the developing storage organ of sweetpotato (Solis, 2012) and potato (Pais et al., 2010; Poovaiah et al., 1996; Raices et al., 2003; Reddy et al., 2002). The accession numbers of the expressed sequence tags used for designing primers for this study are provided in Table 1.

EXPERIMENTAL DESIGN AND STATISTICAL ANALYSES. The greenhouse experiments were conducted in a completely randomized design, whereas the field experiments were conducted as a randomized complete block design using planting dates as replicates. Data were analyzed using the Proc GLM module in SAS (SAS Institute, Cary, NC).

\section{Results}

DROUGHT STRESS STUDIES UNDER GREENHOUSE CONDITIONS. Drought stress treatment in two separate greenhouse trials showed a negative effect on the growth of sweetpotato SRs (Table 2). A reduction in the number, size, and weight of SRs was observed in the drought-stressed plants in comparison with the control plants. The number of SRs (SRCount1), which included all thickened and pigmented (putative) SRs, decreased by $43 \%$ in Trial 1 and by $30 \%$ in Trial 2 under moderate 5 DAT drought stress (Table 2). Using more conservative counts [SRCount2 (excluding pigmented putative forming SRs)], the 
Table 2. Effect of drought stress under greenhouse conditions on sweetpotato storage root growth. ${ }^{z}$

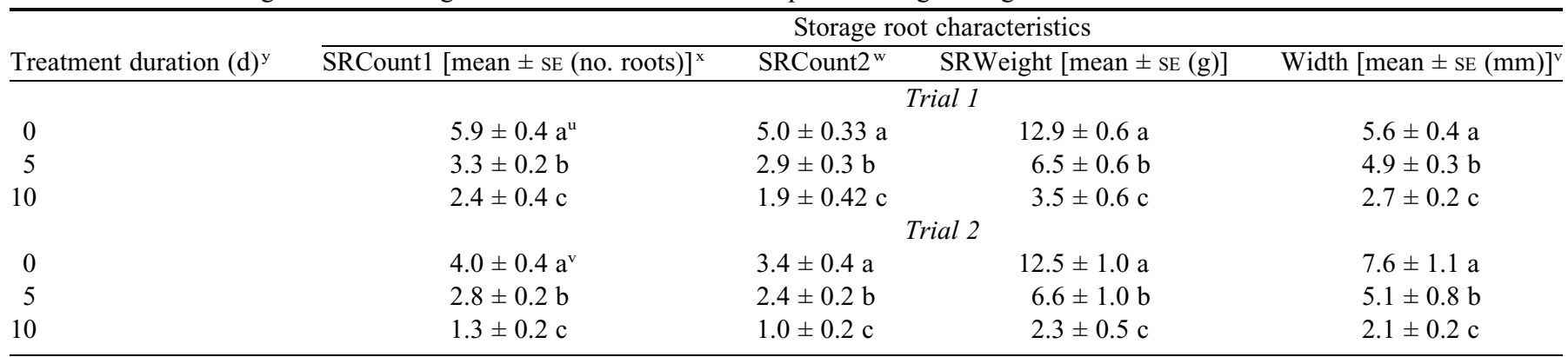

${ }^{\mathrm{z}}$ Data on sweetpotato storage root number, weight, and width under control (well-watered) and drought (no watering for 5 and $10 \mathrm{~d}$ after transplanting). Trial 1 from 30 Jan. to 10 Mar. 2011; Trial 2 from 9 May to 21 June 2011.

${ }^{y}$ Number of days without receiving first watering after transplanting.

${ }^{\mathrm{x}} \mathrm{Number}$ of storage roots including the pigmented roots (i.e., putative initiating storage roots with an estimated maximum diameter less than $1.50 \mathrm{~mm})$

wnumber of storage roots excluding the pigmented roots.

${ }^{v}$ Average of all measurements of maximum width of the storage roots.

"Means with the same letter within a column and trial are not significantly different by Fisher's exact test at $P<0.05$.

reductions were $42 \%$ and $29 \%$ in Trials 1 and 2 , respectively, between 5 DAT drought stress vs. control plants. The reduction in SRCount1 at 10 DAT drought stress was greater compared with that at 5 DAT drought stress with a reduction of $59 \%$ and 67\% in both Trial 2 and Trial 1, respectively. The SRCount2 at 10 DAT drought stress showed a reduction of $71 \%$ in Trial 1 and $62 \%$ in Trial 2.

All plants reached similar foliar growth at the time of harvest and no death occurred as a result of drought stress under greenhouse conditions. Plants under drought stress showed moderate to severe stress effects in terms of reduction of weight and the maximum diameter of the SRs compared with the control. For example, the weight of the SRs was $50 \%$ and $73 \%$ less in plants experiencing 5 and 10 DAT drought stress, respectively, in comparison with the control in Trial 1 (Table 2). Reduction in SR weight followed a similar trend in Trial 2 (Table 2). Maximum diameter of the SRs was $13 \%$ and $51 \%$ less in plants experiencing drought stress of 5 and 10 DAT, respectively, in comparison with the control in Trial 1. Reductions were more pronounced in Trial 2.

DROUGHT STRESS STUDIES UNDER FIELD CONDITIONS. The results of field experiments of combined data from 2010 and 2011 seasons showed that the yield of sweetpotato plants experiencing drought stress under field conditions was reduced significantly (Table 3 ). The yield reduction was most pronounced for the important U.S. \#1 grade; non-irrigated plots showed a $49 \%$ yield reduction compared with the irrigated plots. The total marketable root yield showed similar trends with a reduction of $43 \%$ in the non-irrigated plots compared with the control. The jumbo and medium grades were not significantly different and consistent with high replication variability typically encountered in sweetpotato yield studies.

GENE EXPRESSION UNDER GREENHOUSE DROUGHT STRESS. Ten of 19 genes tested were found up-regulated in drought-stressed roots with fold change expression of at least 1.4 relative to control (IbAREB; IbBEL1, 2, 3; IbCBP2; IbCRF1;IbHB1, 2; $I b K n 2,3 a)$, and only two genes (IbCBPI and $I b C D P K 3)$ were down-regulated (Fig. 2). Expression levels for IbBEL2, Ibkn2, and $I b C R F 2$ genes correspond to a single set of triplicate sample treatments, and for the rest of the genes, the expression levels are as described in "Materials and Methods" (two independent sets of triplicate samples). Of the up-regulated genes, nine were transcription factors and the other $(I b C B P 2)$ coded for a calciumbinding protein.

Three genes, IbHB2 (encoding a homeobox protein), $I b C R F 1$ (encoding a protein similar to the Arabidopsis thaliana cytokinin response factor 1), and IbAREB (encoding an abscisic acid-responsive elements-binding factor), showed very high accumulation of their transcripts under drought stress imposed 5 DAT in comparison with the control. The greatest increase in abundance of transcript under drought stress was observed for $\mathrm{IbHB2}$.

BELL (IbBEL1, IbBEL2, and IbBEL3) and KNOX (Ibkn3a) transcription factors were up-regulated 1.4- to 2.2-fold in roots of plants that were under drought stress. Two genes, IbDREB 1 and $I b G R F$, did not show significant differences in their expression between roots of drought-stressed and control plants, whereas expression changes of IbSnRK and IbTAP were inconsistent (data not shown).

Of the down-regulated genes, only $I b C B P 1$, encoding a calcium-binding protein, showed the greatest reduction of expression up to $80 \%$ (fold change 0.22 ) in roots under greenhouse drought stress compared with the control, and a slight decrease (fold change 0.76) of transcript abundance was observed for $I b C D P K 3$, a gene putatively encoding a calcium-dependent protein kinase (Fig. 2).

Table 3. Combined storage root yield of sweetpotato in response to irrigation treatments under field conditions after $110 \mathrm{~d}$ (in 2010) and $130 \mathrm{~d}$ (in 2011) of growth, Chase, LA.

\begin{tabular}{llccc}
\hline & \multicolumn{4}{c}{ Avg yield $\left(\mathrm{t} \cdot \mathrm{ha}^{-1}\right)^{\mathrm{z}}$} \\
\cline { 2 - 5 } Treatment & U.S. \#1 & Medium & Jumbo & Total marketable \\
\hline Irrigated & $26.5 \mathrm{a}^{\mathrm{y}}$ & $12.4 \mathrm{a}$ & $6.4 \mathrm{a}$ & $45.2 \mathrm{a}$ \\
Non-irrigated & $13.0 \mathrm{~b}$ & $9.9 \mathrm{a}$ & $2.8 \mathrm{a}$ & $25.8 \mathrm{~b}$ \\
$P$ value & $<0.0001$ & 0.2 & 0.2 & $<0.0001$ \\
\hline
\end{tabular}

${ }^{\mathrm{z}}$ Sizes of roots: U.S. \#1 51 to $89 \mathrm{~mm}$ in diameter, 76 to $229 \mathrm{~mm}$ long; medium (canner): 25 to $51 \mathrm{~mm}$ in diameter, 51 to $178 \mathrm{~mm}$ long; jumbo: larger than U.S. \#1 in diameter, length or both, and without objectionable defects. Total marketable represents the summation of all grades. ${ }^{\mathrm{y}}$ Means with the same letter within a column are not significantly different by Fisher's exact test at $P<0.05$. 


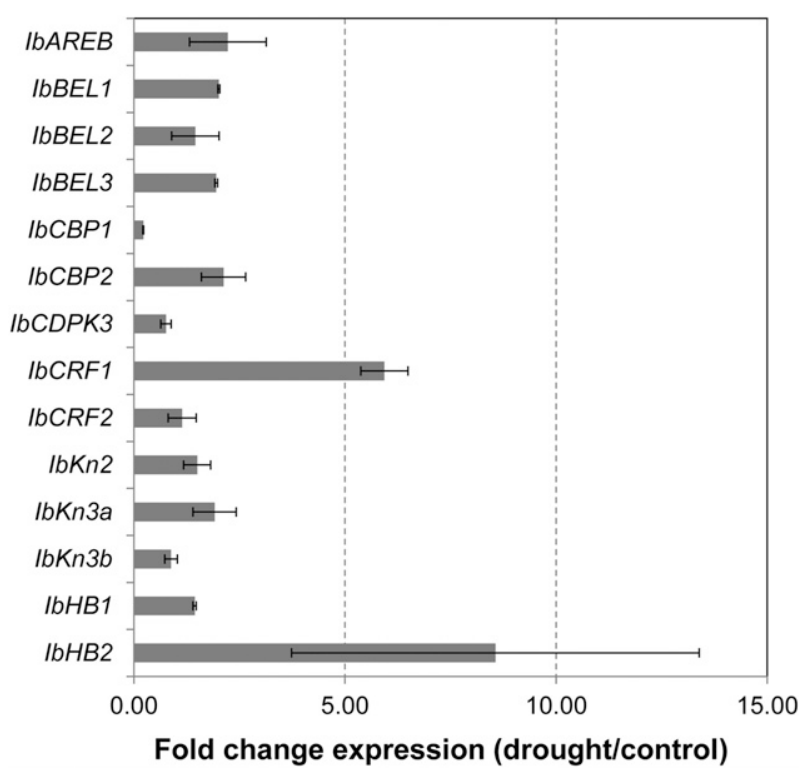

Fig. 2. Expression profile of 14 genes in sweetpotato roots from 2-week-old plants under greenhouse drought stress ( $5 \mathrm{~d}$ after transplanting) vs. control by quantitative real-time polymerase chain reaction. Error bars represent SEM of two independent experiments averaged over three replications each except $I b B E L 2, I b k n 2$, and IbCRF2, where the SE was calculated over the mean of three replicates in a single experiment. Fold change in expression of the genes was determined by normalizing the values against that of the reference gene $I b E F 1 a$ and calculated relative to the control that was set to 1.0.

\section{Discussion}

Drought And Storage Root. Drought stress under greenhouse conditions significantly reduced the number, size, and weight of sweetpotato SRs compared with the control plants (Table 2). The 5 DAT treatments showed a $30 \%$ to $42 \%$ reduction in SR number across the two studies. SR numbers were reduced further (up to $66 \%$ ) by extending the drought period to 10 DAT. Results at 5 and 10 DAT were consistent over two sets of experiments and demonstrated the effect soil moisture could exert on SR formation. Preliminary experiments carried out in growth chambers in 2008 and 2009 under controlled conditions of humidity, daylight, and temperature had a similar outcome (Solis, 2012).

The 2010 and 2011 growing seasons in Louisiana were characterized by prolonged periods without rainfall, especially during the critical period of SR initiation in field-grown 'Beauregard' (Villordon et al., 2009b). This growing environment allowed for the comparison of irrigated vs. non-irrigated treatments on SR initiation and subsequent SR bulking without the confounding effects of natural rainfall events.

In each year, there was marginal soil moisture (less than $25 \%$ to $50 \%$ of $\mathrm{FC}$ ) during the transplanting phase in the non-irrigated plots. This allowed for some SR initiation; however, the lack of additional soil moisture up to 30 DAT impacted further development, resulting in low SR count and delayed SR development. At harvest (110 to 130 DAT), irrigated plots showed over a 100\% increase in U.S. \#1 yield relative to non-irrigated (up to 30 DAT) plots (Table 3 ). Adequate soil moisture after $30 \mathrm{~d}$ did not overcome the effects of the initial drought. These data corroborated earlier findings of Togari (1950) that provided evidence that environmental and management variables during the first
20 DAT exert considerable influence on SR formation, dictating the future yield of the crop.

The reduction of yield and quality of roots observed in the non-irrigated field and the reduced number, diameter, and weight of SRs under greenhouse drought conditions support our hypothesis that lack of soil moisture irreparably alters root development toward non-storage-forming roots.

Gene Expression. Several key genes were shown to be involved in sweetpotato SR development by comparing storage and non-storage-forming roots (Firon et al., 2013; Kim et al., 2002, 2005; Ku et al., 2008; Noh et al., 2010; Tanaka et al., 2008; You et al., 2003). Kim et al. (2009) focused primarily on the identification and study of genes from fibrous roots under drought stress at the late growth stage. The present study focused on gene expression profile of 2-week-old total root pools from non-stressed and drought-stressed plants (5 DAT) at an early stage of growth. The genes included in this study were selected based on comparative analysis of the available sweetpotato root transcriptome (Firon et al., 2013), expressed sequence tag sequences deposited at GenBank and PlantGDB, and sequences from leaf and stem libraries of drought-stressed sweetpotato plants (Schafleitner et al., 2010).

Номеовох LEUCINE ZIPPERS, AP2/EREBP, AND ABSCISIC ACID RESPONSIVE-LIKE GENES. Among the genes that had the highest up-regulation in sweetpotato roots under drought stress were $I b H B 2, I b C R F 1$, and $I b A R E B$ (Fig. 2). The sweetpotato gene $I b H B 2$ is an ortholog of $A T H B 7$ (At2g46680) and a member of the homeobox leucine zipper transcription factors (HD-Zip). Transcripts of $A T H B$ accumulated in response to water stress in A. thaliana (Olsson et al., 2004; Soderman et al., 1996). HD-Zip genes are implicated in both developmental changes and stress responses in A. thaliana (Hjellström, 2002; Lee and Chun, 1998; Soderman et al., 1999) and cassava (Lokko et al., 2007) and dehydration tolerance in the root and leaves of resurrection plant [Craterostigma plantagineum (Deng et al., 2002)]. Furthermore, gradual reduction of expression of the cotton (Gossypium hirsutum) HD-Zip gene (GhHB1) with development of roots and its induction in response to abscisic acid and salt (Ni et al., 2008) indicated that HD-Zip genes play important roles in both morphogenic processes as well as stress responses of plants.

The sweetpotato gene $I b C R F 1$ that showed the second highest increase in expression (fold change of 6) under drought stress is similar to AP2/EREBP genes (Riechmann and Meyerowitz, 1998) and cytokinin response genes (Rashotte and Goertzen, 2010). Expression of many members of the AP2/EREBP gene family is altered in response to abiotic (Chen et al., 2007; Kim et al., 2008; Kizis et al., 2001; Xiong et al., 2002) and biotic stresses (Lin et al., 2007). Although CRF-like genes have not been studied previously in sweetpotato, cytokinins were shown to induce SR organs in sweetpotato (Eguchi and Yoshida, 2008). Therefore, it is presumed that $I b C R F 1$, being a cytokinin responsive gene, could play an important role in SR development under water stress.

НомЕОВоХ BELL AND KNOX I GENES. KNOX (knotted1-like homeobox) genes have been previously found to be associated with the formation of SRs (Tanaka et al., 2008). In the present study, three BELL (BEL1-Like) genes IbBEL1, IbBEL2, and $I b B E L 3$, and $K N O X$ genes $I b k n 1, I b k n 2$, and $I b k n 3$ were upregulated $\approx 1.4$ to two times in 2 -week-old sweetpotato roots in response to drought stress (Fig. 2). In sweetpotato, two variants of Ibkn3 (Ibkn3a and Ibkn3b) were identified (Solis, 2012). $I b k n 3 a$ showed $\approx 2$-fold higher expression under drought over 
a control, whereas $I b k n 3 b$ was slightly down-regulated under drought stress (fold change of 0.88 ). BELL and KNOX proteins are known to interact during potato tuberization (Chen et al., 2003), IbCRF1 and IbCRF2, under drought stress. Further functional characterization of the cytokinin signaling by $K N O X$ and BELL genes is required in sweetpotato to understand the mechanism of their role in abiotic stress response and SR development.

Calcium Signaling Genes. In the present study, the $I b C B P 2$ gene, an ortholog of $A$. thaliana iqd9 (At2g33990) encoding calmodulin binding protein, was up-regulated (fold change of 2.12), whereas two other genes encoding calcium-binding proteins, $I b C B P 1$ and $I b C D P K 3$, were down-regulated under drought stress. $C B P$-like genes were shown to be involved in potato tuberization (Poovaiah et al., 1996; Reddy et al., 2002). Similarly calcium-binding proteins such as CDPKs and calcineurin-B-like genes were shown to be induced by drought and salt stresses (Jimenez et al., 2008). Therefore, it remains to be seen if strict regulation of $C B P$-like genes are required to trigger SR formation in sweetpotato by modulating other downstream stress-related genes under drought stress (Albrecht et al., 2003; Cheong et al., 2003).

Other regulatory Genes. Genes such as $I b G R F$ and $I b D R E B 1$ did not show significant differences between roots of drought-stressed and control plants, but these genes (IbDREB1, $I b G R F, I b S n R K$, and IbTAP) were shown be abundant in SR libraries compared with that from lignified roots based on their digital expression profile in sweetpotato root (Solis, 2012). Inconsistent expression observed for $I b S n R K$ and $I b T A P$ between replicates in the present study was attributed to the difference in greenhouse temperatures during growth stages and at root sampling.

\section{Conclusions}

The present study showed drought stress significantly affects SR number and development in sweetpotato. The expression of genes (IbHB2, IbCRF1, and IbAREB), not previously documented in sweetpotato, were significantly altered in response to drought stress as observed in other species. This work furthermore demonstrated, for the first time, that genes such as IbBEL1, $I b B E L 2, I b B E L 3, I b H B 2$, and Ibkn3a are stress-responsive genes and are up-regulated in roots under greenhouse drought stress conditions. The overall results indicated that genes known to be associated with the onset of bulking are sensitive to drought stress and the consequence is a diminished number of sweetpotato SRs under stress. Altered expression of transcripts of signaling genes $(I b C B P 1, I b C B P 2$, and $I b C D P K 3)$ could be related to the reduced number of SRs. Detailed studies are required to precisely determine the role of up-regulated genes in SR under drought stress, which could potentially be used as biomarkers to identify the effect of water stress on SR development.

\section{Literature Cited}

Albrecht, V., S. Weinl, D. Blazevic, C. D’Angelo, O. Batistic, U. Kolukisaoglu, R. Bock, B. Schulz, K. Harter, and J. Kudla. 2003. The calcium sensor $C B L 1$ integrates plant responses to abiotic stresses. Plant J. 36:457-470.

Blunden, J. and D.S. Arndt. 2012. State of the climate in 2011. Bull. Amer. Meteorol. Soc. 93:S1-S282.

Boyer, J.S. 1982. Plant productivity and environment. Science 218:443-448.
Chen, H., F.M. Rosin, S. Prat, and D.J. Hannapel. 2003. Interacting transcription factors from the three-amino acid loop extension superclass regulate tuber formation. Plant Physiol. 132:13911404.

Chen, M., Q.Y. Wang, X.G. Cheng, Z.S. Xu, A.C.L. Li, X.G. Ye, L.Q. Xia, and Y.Z. Ma. 2007. GmDREB2, a soybean DRE-binding transcription factor, conferred drought and high-salt tolerance in transgenic plants. Biochem. Biophys. Res. Commun. 353:299-305.

Cheong, Y.H., K.N. Kim, G.K. Pandey, R. Gupta, J.J. Grant, and S. Luan. 2003. CBL1, a calcium sensor that differentially regulates salt, drought, and cold responses in Arabidopsis. Plant Cell 15:18331845 .

Choi, H.I., J.H. Hong, J.O. Ha, J.Y. Kang, and S.Y. Kim. 2000. ABFs, a family of ABA-responsive element binding factors. J. Biol. Chem. 275:1723-1730.

Choi, H.I., H.J. Park, J.H. Park, S. Kim, M.Y. Im, H.H. Seo, Y.W. Kim, I. Hwang, and S.Y. Kim. 2005. Arabidopsis calcium-dependent protein kinase AtCPK32 interacts with ABF4, a transcriptional regulator of abscisic acid-responsive gene expression, and modulates its activity. Plant Physiol. 139:1750-1761.

Constantin, R.J., T.P. Hernandez, and L.G. Jones. 1974. Effects of irrigation and nitrogen fertilization on quality of sweet potatoes. J. Amer. Soc. Hort. Sci. 99:308-310.

Deng, X., J. Phillips, A.H. Meijer, F. Salamini, and D. Bartels. 2002. Characterization of five novel dehydration-responsive homeodomain leucine zipper genes from the resurrection plant Craterostigma plantagineum. Plant Mol. Biol. 49:601-610.

de Souza, C.R.B., L. Carvalho, and J.C.D. Cascardo. 2004. Comparative gene expression study to identify genes possibly related to storage root formation in cassava. Protein Pept. Lett. 11:577-582.

Effendy, J., D. La Bonte, and N. Baisakh. 2013. Identification and expression of skinning injury responsive genes in sweetpotato. J. Amer. Soc. Hort. Sci. 138:1-7.

Eguchi, T. and S. Yoshida. 2008. Effects of application of sucrose and cytokinin to roots on the formation of tuberous roots in sweetpotato [Ipomoea batatas (L.) Lam.]. Plant Root 2:7-13.

Ekanayake, I.J. and J.H. Dodds. 1993. In vitro testing for the effects of salt stress on growth and survival of sweetpotato. Sci. Hort. 55:239248.

Firon, N., D. LaBonte, A. Villordon, Y. Kfir, J. Solis, E. Lapis, T.S. Perlman, A. Doron-Faigenboim, A. Hetzroni, L. Althan, and L.A. Nadir. 2013. Transcriptional profiling of sweetpotato (Ipomoea batatas) roots indicates down-regulation of lignin biosynthesis and up-regulation of starch biosynthesis at an early stage of storage root formation. BMC Genomics 14:460.

Hjellström, M. 2002. Drought stress signal transduction by the HD-Zip transcription factors $A T H B 6$ and $A T H B 7$. Acta Universitatis Upsaliensis. Comprehensive Summaries Uppsala diss., Faculty Sci. Technol. 690:18.

Jimenez, J.A., A. Alonso-Ramirez, and C. Nicolas. 2008. Two cDNA clones $\left(F_{S} D h n 1\right.$ and $\left.F_{S} C l o l\right)$ up-regulated by ABA are involved in drought responses in Fasus sylvatica L. seeds. J. Plant Physiol. 165:1798-1807.

Kim, S.H., T. Hamada, M. Otani, and T. Shimada. 2005. Isolation and characterization of MADS box genes possibly related to root development in sweetpotato (Ipomoea batatas L. Lam.). J. Plant Biol. 48:387-393.

Kim, S.H., K. Mizuno, and T. Fujimura. 2002. Isolation of MADS-box genes from sweet potato [Ipomoea batatas (L.) Lam.] expressed specifically in vegetative tissues. Plant Cell Physiol. 43:314-322.

Kim, S.H., W.K. Song, Y.H. Kim, S.Y. Kwon, H.S. Lee, I.C. Lee, and S.S. Kwak. 2009. Characterization of full-length enriched expressed sequence tags of dehydration-treated white fibrous roots of sweetpotato. BMB Rpt. 42:271-276.

Kim, Y.H., J.C. Jeong, H.S. Lee, and S.S. Kwak. 2013. Comparative characterization of sweetpotato antioxidant genes from expressed sequence tags of dehydration-treated fibrous roots under different abiotic stress conditions. Mol. Biol. Rpt. 40:2887-2896. 
Kim, Y.H., K.S. Yang, S.H. Ryu, K.Y. Kim, W.K. Song, S.Y. Kwon, H.S. Lee, J.W. Bang, and S.S. Kwak. 2008. Molecular characterization of a cDNA encoding DRE-binding transcription factor from dehydration-treated fibrous roots of sweetpotato. Plant Physiol. Biochem. 46:196-204.

Kizis, D., V. Lumbreras, and M. Pages. 2001. Role of AP2/EREBP transcription factors in gene regulation during abiotic stress. FEBS Lett. 498:187-189.

Ku, A.T., Y.S. Huang, Y.S. Wang, D. Ma, and K.W. Yeh. 2008. IbMADS1 (Ipomoea batatas MADS-box 1 gene) is involved in tuberous root initiation in sweet potato (Ipomoea batatas). Ann. Bot. (Lond.) 102:57-67.

Lee, Y.H. and J.Y. Chun. 1998. A new homeodomain-leucine zipper gene from Arabidopsis thaliana induced by water stress and abscisic acid treatment. Plant Mol. Biol. 37:377-384.

Ley, T.W., R.G. Stevens, R.R. Topielec, and W.H. Neibling. 1994. Soil water monitoring and measurement. Washington State Univ., Pacific Northwest Ext. Publ. 475.

Lin, R., W. Zhao, X. Meng, and Y.L. Peng. 2007. Molecular cloning and characterization of a rice gene encoding AP2/EREBP-type transcription factor and its expression in response to infection with blast fungus and abiotic stresses. Physiol. Mol. Plant Pathol. 70:60-68.

Lokko, Y., J.V. Anderson, S. Rudd, A. Raji, D. Horvath, M.A. Mikel, R. Kim, L. Liu, A. Hernandez, A.G.O. Dixon, and I.L. Ingelbrecht. 2007. Characterization of an 18,166 EST dataset for cassava (Manihot esculenta Crantz) enriched for drought-responsive genes. Plant Cell Rpt. 26:1605-1618.

National Oceanic and Atmospheric Administration. 2014. Monthly climatological summary 2010, 2011. 1 Jan. 2014. <http://www. ncdc.noaa.gov/cdo-web/datasets/GHCNDMS/stations/GHCND: USC00169806/detail>.

Ni, Y.X., X.L. Wang, D.D. Li, Y.J. Wu, W.L. Xu, and X.B. Li. 2008. Novel cotton homeobox gene and its expression profiling in root development and in response to stresses and phytohormones. Acta Biochim. Biophys. Sin. (Shanghai) 40:78-84.

Noh, S.A., H.S. Lee, E.J. Huh, G.H. Huh, K.H. Paek, J.S. Shin, and J.M. Bae. 2010. SRDI is involved in the auxin-mediated initial thickening growth of storage root by enhancing proliferation of metaxylem and cambium cells in sweetpotato (Ipomoea batatas). J. Expt. Bot. 61:1337-1349.

Olsson, A.S.B., P. Engstrom, and E. Soderman. 2004. The homeobox genes $A T H B 12$ and $A T H B 7$ encode potential regulators of growth in response to water deficit in Arabidopsis. Plant Mol. Biol. 55:663-677.

Pais, S.M., M.N. Garcia, M.T. Tellez-Inon, and D.A. Capiati. 2010. Protein phosphatases type $2 \mathrm{~A}$ mediate tuberization signaling in Solanum tuberosum L. leaves. Planta 232:37-49.

Park, S.C., Y.H. Kim, J.C. Jeong, C.Y. Kim, H.S. Lee, J.W. Bang, and S.S. Kwak. 2011. Sweetpotato late embryogenesis abundant 14 (IbLEA14) gene influences lignification and increases osmotic- and salt stress-tolerance of transgenic calli. Planta 233:621-634.

Poovaiah, B.W., D. Takezawa, G. An, and T.J. Han. 1996. Regulated expression of a calmodulin isoform alters growth and development in potato. J. Plant Physiol. 149:553-558.

Raices, M., P.R. Gargantini, D. Chinchilla, M. Crespi, M.T. TellezInon, and R.M. Ulloa. 2003. Regulation of CDPK isoforms during tuber development. Plant Mol. Biol. 52:1011-1024.

Rashotte, A.M. and L.R. Goertzen. 2010. The CRF domain defines cytokinin response factor proteins in plants. BMC Plant Biol. 10:74.

Reddy, A.S.N., I.S. Day, S.B. Narasimhulu, F. Safadi, V.S. Reddy, M. Golovkin, and M.J. Harnly. 2002. Isolation and characterization of a novel calmodulin-binding protein from potato. J. Biol. Chem. 277:4206-4214.

Ricardo, J. 2011. Screening sweetpotato (Ipomoea batatas L.) for drought tolerance and high $\beta$-carotene content. MS thesis, Univ. KwaZulu-Natal, Pietermaritzburg, South Africa.

Rickard, D.S. and P.D. Fitzgerald. 1969. The estimation and occurrence of agricultural drought. J. Hydrol. (Amst.) 8:11-16.

Riechmann, J.L. and E.M. Meyerowitz. 1998. The AP2/EREBP family of plant transcription factors. Biol. Chem. 379:633-646.

Rus, A., I. Baxter, B. Muthukumar, J. Gustin, B. Lahner, E. Yakubova, and D.E. Salt. 2006. Natural variants of AtHKT1 enhance $\mathrm{Na}+$ accumulation in two wild populations of Arabidopsis. PLoS Genet. 2:e210.

Saraswati, P. 2007. Physiological and growth responses of selected sweet potato [Ipomoea batatas (L.) Lam.] cultivars to water stress. PhD diss., James Cook Univ., Townsville City, Australia.

Schafleitner, R., L.R. Tincopa, O. Palomino, G. Rossel, R.F. Robles, R. Alagon, C. Rivera, C. Quispe, L. Rojas, J.A. Pacheco, J. Solis, D. Cerna, J.Y. Kim, J. Hou, and R. Simon. 2010. A sweetpotato gene index established by de novo assembly of pyrosequencing and Sanger sequences and mining for gene-based microsatellite markers. BMC Genomics 11:604.

Soderman, E., M. Hjellström, J. Fahleson, and P. Engstrom. 1999. The HD-Zip gene ATHB6 in Arabidopsis is expressed in developing leaves, roots and carpels and up-regulated by water deficit conditions. Plant Mol. Biol. 40:1073-1083.

Soderman, E., J. Mattsson, and P. Engstrom. 1996. The Arabidopsis homeobox gene ATHB-7 is induced by water deficit and by abscisic acid. Plant J. 10:375-381.

Solis, J. 2012. Genomic approaches to understand sweetpotato root development in relation to abiotic factors. PhD diss., Louisiana State Univ., Baton Rouge, LA.

Tanaka, M., N. Kato, H. Nakayama, M. Nakatani, and Y. Takahata. 2008. Expression of class I knottedl-like homeobox genes in the storage roots of sweetpotato (Ipomoea batatas). J. Plant Physiol. 165:1726-1735.

Togari, Y. 1950. A study of tuberous root formation in sweet potato. Bul. Natl. Agr. Expt. Stn. 68:1-96.

USDA. 2005. United States standards for grades of sweetpotato. 2 Apr. 2014. <http://www.ams.usda.gov/AMSv1.0/getfile?dDocName= STELPRDC5050330>.

Villordon, A., D. LaBonte, and J. Solis. 2011. Using a scanner-based minirhizotron system to characterize sweetpotato adventitious root development during the initial storage root bulking stage. HortScience 46:513-517.

Villordon, A.Q., D.R. LaBonte, N. Firon, Y. Kfir, E. Pressman, and A. Schwartz. 2009a. Characterization of adventitious root development in sweetpotato. HortScience 44:651-655.

Villordon, A., D. LaBonte, and N. Firon. 2009b. Development of a simple thermal time method for describing the onset of morphoanatomical features related to sweetpotato storage root formation. Sci. Hort. 121:374-377.

Villordon, A., J. Solis, D. LaBonte, and C. Clark. 2010. Development of a prototype Bayesian network model representing the relationship between fresh market yield and some agroclimatic variables known to influence storage root initiation in sweetpotato. HortScience 45:1167-1177.

Xiong, L.M., K.S. Schumaker, and J.K. Zhu. 2002. Cell signaling during cold, drought, and salt stress. Plant Cell 14:S165-S183.

You, M.K., C.G. Hur, Y.S. Ahn, M.C. Suh, B.C. Jeong, J.S. Shin, and J.M. Bae. 2003. Identification of genes possibly related to storage root induction in sweetpotato. FEBS Lett. 536:101-105. 